\title{
The Plasma Sugar, Free Fatty Acid, Cortisol, and Growth Hormone Response to Insulin. I. In Control Subjects *
}

\author{
F. C. Greenwood $†$ J. Landon, $\$$ and T. C. B. Stamp $\S$ \\ (From the Division of Chemistry \& Biochemistry, Imperial Cancer Research Fund, Lincoln's \\ Inn Fields, and the Alexander Simpson Laboratories for Metabolic Research, De- \\ partment of Chemical Pathology, St. Mary's Hospital, London, England)
}

The sequence of events that follows the intravenous injection of insulin has been reviewed extensively by De Bodo and Altszuler (1). A complex set of mechanisms normally operates to antagonize the action of insulin, thereby limiting the extent to which the blood glucose falls and causing a rapid return to original levels. There is evidence that glucocorticoids and growth hormone play an important role as hormonal insulin antagonists. Thus both Addison's disease and hypopituitarism are known to be associated with increased insulin sensitivity, whereas patients with Cushing's syndrome or acromegaly are resistant to its hypoglycemic action $(2,3)$. The observation that the intravenous injection of insulin into control subjects results in rapid elevations of plasma cortisol $(4,5)$ and growth hormone $(6-9)$ also supports the possible physiologic importance of these hormones as insulin antagonists. Since the release of these two hormones depends on adequate hypothalamic as well as pituitary and adrenal function $(5,7,10)$, it was apparent that a rapid test of both the hypothalamo-pituitary-adrenal axis for the secretion of cortisol and the hypothalamo-pituitary axis for the secretion of growth hormone could be developed with insulininduced hypoglycemia as a stimulus.

The present paper describes the time sequence of the changes in plasma sugar, free fatty acids (FFA), cortisol, and growth hormone in normal

\footnotetext{
* Submitted for publication September 21, 1965; accepted December 2, 1965.

$\dagger$ Address requests for reprints to Dr. F. C. Greenwood, Division of Chemistry \& Biochemistry, Imperial Cancer Research Fund, Lincoln's Inn Fields, London, W.C.2, England.

$¥$ This work was carried out during the tenure of a Ciba Research Fellowship.

$\S$ Recipient of a Medical Research Council grant.
}

subjects given insulin, the reproducibility of these responses, and the variation in response with different doses of insulin. A normal range of response has been defined so that similar tests performed in patients with a variety of endocrine and other disorders $(11,12)$ could be interpreted.

\section{Methods}

Fifty-four tests were carried out in 38 subjects, of whom 12 were members of the medical staff and the remainder patients who were not malnourished and who had no clinical or biochemical evidence of endocrine, hepatic, or renal dysfunction. The subjects' weights ranged from 78 to $142 \%$ of their ideal body weights and their ages from 18 to 34 years.

The tests were commenced between 9 and 10 a.m. after an overnight fast of 12 to 14 hours. The subjects were kept at rest in the horizontal position for 1 hour before the first blood sample to minimize the effects of previous exercise. An indwelling needle was inserted into a forearm vein 30 minutes before the first sample was taken to minimize the possible effects of stress. A second sample was taken 45 minutes after the insertion of the indwelling needle. The needle was kept patent between samples by the introduction of a small amount of citrate, a $1-\mathrm{ml}$ waste sample being discarded before taking each blood specimen to avoid contamination by the citrate. After two samples had been taken at 15minute intervals, the appropriate amount of glucagonfree soluble insulin ( 0.025 to $0.15 \mathrm{U}$ per $\mathrm{kg}$ body weight) was injected intravenously. Blood samples were then taken at 10-minute intervals for 1 hour and at 15-minute intervals for a further hour. In five control studies the test was performed in exactly the same way, but saline was substituted for insulin.

The blood was placed in heparinized tubes and immediately centrifuged. The plasma sugar and FFA concentrations were determined in all samples. Plasma cortisol and growth hormone concentrations were determined for the two samples taken before the injection of insulin and for the 20-, 30-, 60-, 90-, and 120-minute samples. All samples were stored frozen before analysis.

Injection of $0.1 \mathrm{U}$ per $\mathrm{kg}$ or more of soluble insulin usually resulted in transient symptoms after about 20 
TABLE I

Levels of plasma sugar, FFA, cortisol, and growth hormone in control subjects rested after overnight fasting

\begin{tabular}{lccccc}
\hline \hline & $\begin{array}{c}\text { No. of } \\
\text { subjects }\end{array}$ & $\begin{array}{c}\text { No. of } \\
\text { determin- } \\
\text { ations }\end{array}$ & Mean \pm SD & Range \\
\hline $\begin{array}{l}\text { Plasma sugar, } m g / 100 m l \\
\text { Plasma FFA, } \mu E q / L\end{array}$ & 38 & 102 & $94 \pm 8.2$ & $75-105$ \\
$\begin{array}{l}\text { Plasma cortisol, } \\
\quad \mu g / 100 m l\end{array}$ & 25 & 74 & $610 \pm 121$ & $370-880$ \\
$\begin{array}{l}\text { Plasma growth hormone, } \\
m \mu g / m l\end{array}$ & 37 & 94 & $12.7 \pm 2.9$ & $6.8-20.2$ \\
& 36 & 92 & $2.6 \pm 3.9$ & $<1-20.4$ \\
\hline
\end{tabular}

minutes. These consisted of drowsiness, excessive perspiration, and hunger, and it was the experience of two of the authors, tested on four separate occasions, that these symptoms were not unduly unpleasant. A physician was present in the ward throughout the test. Glucose for intravenous use was available but was not required.

Plasma sugar concentrations were determined by the ferricyanide method of Hoffman (13) modified for use with a Technicon autoanalyzer. The recorder was set at the highest sensitivity with glucose standards ranging from 0 to $120 \mathrm{mg}$ per $\mathrm{ml}$. The reproducibility of the method in our hands was the mean $\pm 3 \mathrm{mg}$ per $100 \mathrm{ml}$ (SD) and gave values 5 to $10 \mathrm{mg}$ per $100 \mathrm{ml}$ above the results found by a more specific glucose oxidase method (14). FFA levels were determined on freshly extracted plasma by the single extraction method of Dole and Meinertz (15). In our hands the standard error of the method on duplicate titrations of replicate extractions was $\pm 3 \%$. "Cortisol" concentrations were determined on 2-ml samples of plasma by a fluorimetric procedure (16). This method determines essentially cortisol and corticosterone when applied to human plasma, and although the term "plasma cortisol" in this paper is used for convenience, we are aware that both cortisol and corticosterone are being determined. This method gives values similar to those obtained with a colorimetric method (17). Plasma growth hormone values were de- termined by the radioimmunoelectrophoretic method of Hunter and Greenwood (18). Results are expressed as millimicrograms per milliliter plasma with a laboratory standard of human growth hormone prepared by the method of Raben (19) with an additional purification step (18). Immunologically this standard was $150 \%$ of the Medical Research Council's standard A for human growth hormone. Precision data for the method have been published previously (18).

Statistical methods (20) included calculation of the arithmetic mean and standard deviation, the correlation coefficient, the multiple correlation coefficient, and the value for Student's $t$ test.

Quantitative comparisons between plasma values obtained during dynamic tests are difficult when the plasma is not continuously sampled. For comparative purposes we have taken the minima of the plasma sugar and FFA and their recovery index for each test. The latter is the sum of the plasma levels obtained at 60,90 , and $120 \mathrm{~min}-$ utes expressed as a percentage of the value obtained during the control period and gives an index of the rate of recovery of the plasma levels to preinsulin values. For plasma cortisol and growth hormone the maximal levels observed during the test have been used. The maximal increment has also been recorded to reduce these maxima to a common base line of zero. Estimates of response were also obtained by calculating the area of response in the period from 0 to 120 minutes after insulin for the

TABLE II

The mean response of plasma sugar, FFA, cortisol, and growth hormone to increasing amounts of insulin injected intravenously into control subjects

\begin{tabular}{|c|c|c|c|c|c|c|c|c|c|}
\hline \multirow[b]{2}{*}{$\begin{array}{l}\text { No. of } \\
\text { subjects }\end{array}$} & \multirow[b]{2}{*}{ Insulin } & \multicolumn{2}{|c|}{ Plasma sugar } & \multicolumn{2}{|c|}{ Plasma FFA } & \multicolumn{2}{|c|}{ Plasma cortisol } & \multicolumn{2}{|c|}{ Plasma growth hormone } \\
\hline & & Minimum* & $\begin{array}{c}\text { Recovery } \\
\text { indext }\end{array}$ & Minimum* & $\begin{array}{c}\text { Recovery } \\
\text { indext }\end{array}$ & Maximum $\ddagger$ & $\underset{\text { increment }}{\text { Maximal }}$ & Maximum $\ddagger$ & $\underset{\text { increment }}{\text { Maximal }}$ \\
\hline & $U / k g$ & \multicolumn{2}{|c|}{$m g / 100 m l$} & \multicolumn{2}{|c|}{$\mu E q / L$} & \multicolumn{2}{|c|}{$\mu \mathrm{g} / 100 \mathrm{ml}$} & \multicolumn{2}{|c|}{$m \mu g / m l$} \\
\hline 5 & $\begin{array}{c}\text { Saline } \\
\text { only }\end{array}$ & $89.2 \pm 9.0$ & $298 \pm 13$ & $704 \pm 160$ & $329 \pm 35$ & $10.6 \pm 1.9$ & $-2.9 \pm 3.2$ & $1.8 \pm 2.4$ & $0.8 \pm 0.2$ \\
\hline 6 & 0.025 & $60.0 \pm 17.8$ & $291 \pm 16$ & $308 \pm 44$ & $301 \pm 43$ & $11.5 \pm 2.3$ & $-1.6 \pm 1.7$ & $5.7 \pm 3.8$ & $5.2 \pm 3.8$ \\
\hline 5 & 0.05 & $36.2 \pm 3.9$ & $279 \pm 13$ & $290 \pm 15$ & $279 \pm 43$ & $22.5 \pm 8.6$ & $11.6 \pm 5.1$ & $18.6 \pm 7.9$ & $16.1 \pm 8.1$ \\
\hline 6 & 0.10 & $31.5 \pm 8.3$ & $253 \pm 32$ & $288 \pm 42$ & $316 \pm 106$ & $25.0 \pm 1.9$ & $15.0 \pm 3.0$ & $36.2 \pm 20.6$ & $33.1 \pm 22.8$ \\
\hline 6 & 0.15 & $28.5 \pm 3.7$ & $197 \pm 37$ & $370 \pm 63$ & $276 \pm 61$ & $32.3 \pm 4.5$ & $18.7 \pm 3.7$ & $34.5 \pm 26.7$ & $32.7 \pm 27.3$ \\
\hline
\end{tabular}

* Mean \pm standard deviation of the minimal values 0 to 120 minutes after injection.

$\dagger$ Mean \pm standard deviation of the recovery indexes; the sum of the values at 60,90 , and 120 minutes after injection as a percentage of the control value.

$\ddagger$ Mean \pm standard deviation of the maximal values 0 to 120 minutes after injection.

Mean \pm standard deviation of the maximal increment; the maximal value 0 to 120 minutes after injection less value of control sample. 
plasma sugar, FFA, cortisol, and growth hormone for each test by Simpson's rule (21). For this the mean of the two values obtained during the control period before insulin was extrapolated from 0 to 120 minutes and the area subtracted.

\section{Results}

Plasma levels of sugar, FFA, cortisol, and growth hormone in control subjects at rest after overnight fasting. The levels of plasma sugar, FFA, cortisol, and growth hormone were determined for each subject at rest after an overnight fast on from two to eight separate occasions. The mean, standard deviation, and range of values for the four plasma constituents are given in Table I. There was no correlation among the levels of plasma sugar, FFA, cortisol, and growth hormone in each subject.

The method used for growth hormone assay was not sufficiently sensitive to detect circulating levels of growth hormone in all subjects. Thus growth hormone was only detectable in 18 of the 36 subjects over the 92 determinations carried out. The resting level of plasma growth hormone was $4.1 \pm 5.48 \mathrm{~m} \mu \mathrm{g}$ per $\mathrm{ml}$ in the women and $1.7 \pm 2.19$ $\mathrm{m} \mu \mathrm{g}$ per $\mathrm{ml}$ in the men. The difference between these two values is not significant. There was no significant sex difference among the resting levels of plasma sugar, FFA, or cortisol.

The plasma sugar, $F F A$, cortisol, and growth hormone responses to the intravenous injection of insulin ( 0 to $0.15 \mathrm{U}$ per $\mathrm{kg}$ ) in control subjects. The response to various dose levels of insulin ranging from 0.025 to $0.15 \mathrm{U}$ per $\mathrm{kg}$ was studied in 12 members of the medical staff and compared with the values found after the injection of saline. The mean results are shown in Figure 1 and summarized in Table II.

After the injection of insulin there was a prompt fall of the plasma sugar to a minimal value at 20 to 30 minutes. The lowest level reached correlated with the dose of insulin $(r=-0.78, \mathrm{p}<$ $0.001, \mathrm{n}=28$ ). The recovery indexes also correlated with the dose of insulin $(r=-0.83, p<$ $0.001, n=28$ ). There was no significant plasma sugar change after the injection of saline. The mean level of circulating cortisol fell from 13.6 to $10.1 \mu \mathrm{g}$ per $100 \mathrm{ml}$ in the 2 hours after the injection of saline, and a similar fall was found after the injection of $0.025 \mathrm{U}$ per $\mathrm{kg}$ of insulin. With progressively higher doses, a rise in plasma corti-

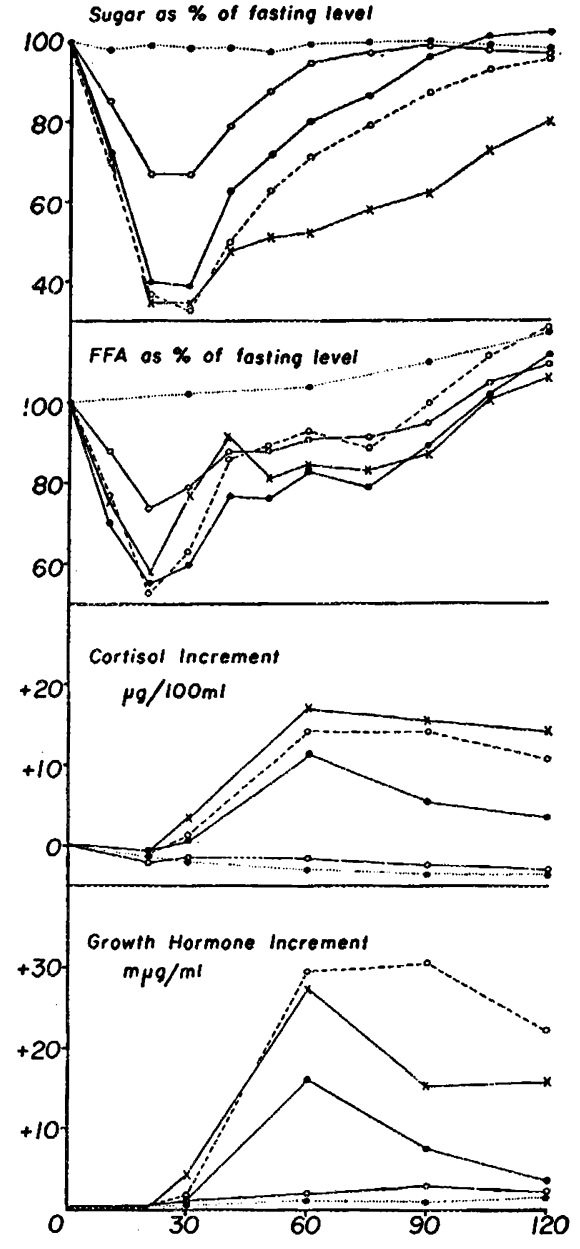

Fig. 1. The plasma sugar, FFA, cortisol, and GROWTH HORMONE RESPONSE TO SALINE ( .........), TO $0.025 \mathrm{U}$ OF INSULIN PER KG (O-O), TO $0.05 \mathrm{U}$ OF INSULIN PER KG (PER KG $(O \ldots \ldots .$.$) , AND TO 0.15$ U OF INSULIN PER KG $(X-X)$ AT $0,30,60,90$, AND 120 MINUTES AFTER INSULIN.

sol was detected after 30 minutes and appeared to be related to the dose of insulin (Figure 1 ).

The mean plasma FFA level increased from 710 to $840 \mu \mathrm{Eq}$ per $\mathrm{L}$ during the 120 -minute test period in the five subjects given saline. The pattern of the FFA response to insulin was similar to that of the plasma sugar, namely a prompt fall followed by a return to preinsulin levels. Unlike the plasma sugar response, however, the minimal level was found at 20 minutes, and although the minimal levels correlated with the insulin dose $(r=-0.42$, $\mathrm{p}<0.05, \mathrm{n}=27$ ), the recovery indexes did not $(\mathrm{r}=-0.24, \mathrm{p}>0.05, \mathrm{n}=27)$. 
In contrast to the findings in relation to the plasma cortisol response to insulin, a significant effect on growth hormone levels was observed in the group of control subjects given $0.025 \mathrm{U}$ per $\mathrm{kg}$ as compared with the values found in the group injected with saline. The variation in response among subjects receiving the same dose of insulin was markedly greater for growth hormone than for cortisol (Table II), and on a molar basis there is a marked difference in the peak plasma concentration of growth hormone $\left(10^{-8} \mathrm{M}\right)$ and cortisol $\left(10^{-6} \mathrm{M}\right)$. Figure 1 shows that the growth hormone response was apparently sustained with an initial rise at 30 minutes reaching maximal levels at 60 or 90 minutes. These values, however, are the mean of markedly fluctuant individual levels. Thus in some subjects two separate growth hormone peaks were found, whereas in one subject given $0.15 \mathrm{U}$ per $\mathrm{kg}$ of insulin the growth hormone levels did not exceed $5 \mathrm{~m} \mu \mathrm{g}$ per $\mathrm{ml}$ until the sample taken at 120 minutes.

A further estimate of the responses was obtained in each subject by calculating the area of the net loss of plasma sugar and FFA and the net gain in plasma cortisol and growth hormone during the test as described previously. The individual values were then used to correlate the responses in plasma sugar with similar estimates of the individual responses in plasma FFA, cortisol, and growth hormone and with the dose of insulin. Correlation coefficients with $\mathrm{p}$ values of less than 0.001 were obtained between insulin and plasma

TABLE III

Summary of the responses to the iv injection of $0.15 \mathrm{U}$ per $\mathrm{kg}$ of insulin in 28 control subjects

\begin{tabular}{|c|c|c|c|c|}
\hline & & Mean & SD & Range \\
\hline $\begin{array}{l}\text { Plasma } \\
\text { sugar }\end{array}$ & $\begin{array}{l}\text { Minimum, } * m g / 100 m l \\
\text { Recovery indext }\end{array}$ & $\begin{array}{r}31 \\
211\end{array}$ & $\begin{array}{r}9 \\
36\end{array}$ & $\begin{array}{c}18-53 \\
161-292\end{array}$ \\
\hline $\begin{array}{c}\text { Plasma } \\
\text { FFA }\end{array}$ & $\begin{array}{l}\text { Minimum, }{ }^{*} \mu E q / L \\
\text { Recovery indext }\end{array}$ & $\begin{array}{l}330 \\
286\end{array}$ & $\begin{array}{l}90 \\
67\end{array}$ & $\begin{array}{l}140-480 \\
188-403\end{array}$ \\
\hline $\begin{array}{l}\text { Plasma } \\
\quad \text { cortisol }\end{array}$ & $\begin{array}{l}\text { Maximum, } \ddagger \mu g / 100 \mathrm{ml} \\
\text { Maximal increment, } \$ \\
\mu \mathrm{g} / 100 \mathrm{ml}\end{array}$ & $\begin{array}{l}28.1 \\
15.4\end{array}$ & $\begin{array}{l}5.0 \\
4.8\end{array}$ & $\begin{array}{r}21.7-37.6 \\
7.7-24.2\end{array}$ \\
\hline $\begin{array}{l}\text { Plasma } \\
\text { growth } \\
\text { hormone }\end{array}$ & $\begin{array}{l}\text { Maximum,t } m \mu g / m l \\
\text { Maximal increment, } \$ \\
m \mu g / m l\end{array}$ & $\begin{array}{l}37.4 \\
35.0\end{array}$ & $\begin{array}{l}25.2 \\
24.9\end{array}$ & $\begin{array}{l}15.1-121.1 \\
1.3 .7-118.6\end{array}$ \\
\hline $\begin{array}{l}* \text { Mean } \pm \\
\text { after injectic } \\
+ \text { Mean } \pm \\
\text { values at } 60 \\
\text { control valu } \\
\mp \text { Mean } \pm \\
\text { after injectic } \\
\text { \& Mean } t \\
\text { mal value } 0\end{array}$ & $\begin{array}{l}\text { Idard deviation of the } \\
\text { Idard deviation of the } \\
\text { and } 120 \text { minutes after } \\
\text { Idard deviation of the } \\
\text { dard deviation of the } \\
0 \text { minutes after injecti }\end{array}$ & $\begin{array}{l}\text { imal } \\
\text { overy } \\
\text { ection } \\
\text { cimal } \\
\text { axima }\end{array}$ & pe 0 & $\begin{array}{l}20 \text { minutes } \\
\text { sum of the } \\
\text { tage of the } \\
20 \text { minutes } \\
\text { the maxi- } \\
\text { rol sample. }\end{array}$ \\
\hline
\end{tabular}

sugar $(r=-0.87)$, insulin dose and plasma cortisol $(r=+0.88)$, and between plasma sugar and plasma cortisol $(r=-0.79)$. Significant correlations $(p<0.05)$ were also obtained between plasma sugar and growth hormone response $(\mathrm{r}=-0.54)$, between insulin dose and growth hormone response $(r=-0.54)$, and between the rises in plasma cortisol and growth hormone $(\mathrm{r}=+0.52)$. The remaining correlations involving the $\mathrm{FFA}$ response were not significant at the $p=0.05$ level, viz., insulin/FFA, $r=-0.37$; sugar/FFA, $r=+0.35 ; \mathrm{FFA} /$ cortisol, $r=-$ $0.35 ; \mathrm{FFA} /$ growth hormone, $\mathrm{r}=-0.28$.

An attempt was made to distinguish between direct and indirect relationships suggested by the significant statistical correlations outlined above. The twelve multiple correlation coefficients were calculated from the six significant correlation coefficients as shown in the following example, where $a=r$ (sugar vs. cortisol), $b=r$ (sugar vs. insulin), and $c=r$ (insulin vs. cortisol) $: r^{\prime}$ (plasma sugar vs. plasma cortisol $)=[a-(b)(c)] /$ $\left(\sqrt{1-b^{2}} \sqrt{1-c^{2}}\right)$.

Relationships remaining significant at $\mathrm{p}$ values of less than 0.001 after these tests were those suggested between insulin dose and plasma sugar response and between insulin dose and plasma cortisol response.

The plasma sugar, FFA, cortisol, and growth hormone responses to the intravenous injection of insulin $(0.15 \mathrm{U}$ per $\mathrm{kg}$ ). A larger group of 28 control subjects was tested at the highest dose level of insulin ( $0.15 \mathrm{U}$ per $\mathrm{kg})$ to study possible sex differences and to establish a normal range of response. The mean, standard deviation, and range of responses are summarized in Table III.

Statistical analysis of results between 22 control patients and the six members of the medical staff whose results are shown in Table II showed no significant differences. Analysis of the combined data for effects of age and of weight (expressed as a percentage of the ideal body weight) showed no significant differences. Similarly there were no significant differences in the responses between the 11 males and 11 females of the series of control patients, apart from the finding that females showed a significantly lower plasma sugar at the minimum $(27 \pm 11 \mathrm{mg}$ per $100 \mathrm{ml}$ ) than males $(36 \pm 11 \mathrm{mg}$ per $100 \mathrm{ml})(\mathrm{p}<0.05)$ and had higher mean levels of plasma cortisol 90 min- 
TABLE IV

Reproducibility of the plasma sugar, FFA, cortisol, and growth hormone response to insulin $(0.15 \mathrm{U}$ per $\mathrm{kg})$ in control subjects

\begin{tabular}{|c|c|c|c|c|c|c|c|c|c|c|c|}
\hline & \multirow{2}{*}{$\begin{array}{l}\text { Subject: } \\
\text { Test: }\end{array}$} & \multicolumn{2}{|c|}{ A } & \multicolumn{2}{|c|}{ B } & \multicolumn{2}{|c|}{ c } & \multicolumn{2}{|c|}{$D$} & \multicolumn{2}{|c|}{$\mathbf{E}$} \\
\hline & & 1 & 2 & 1 & 2 & 1 & 2 & 1 & 2 & 1 & 2 \\
\hline \multirow{2}{*}{$\begin{array}{l}\text { Plasma } \\
\text { sugar }\end{array}$} & Minimum* & 25 & 20 & 23 & 20 & 35 & 40 & 20 & 26 & 30 & 30 \\
\hline & Recovery index $†$ & 205 & 193 & 197 & 245 & 187 & 194 & 122 & 158 & 206 & 211 \\
\hline \multirow{2}{*}{$\underset{\text { FFA }}{\text { Plasma }}$} & Minimum* & 360 & 350 & 260 & 230 & & & & & & \\
\hline & Recovery index $†$ & 309 & 353 & 321 & 244 & & & & & & \\
\hline \multirow{2}{*}{$\begin{array}{l}\text { Plasma } \\
\text { cortisol }\end{array}$} & Maxirnum $\neq$ & 24.8 & 22.6 & 26.7 & 26.6 & 24.5 & 21.5 & 25.2 & 24.8 & & \\
\hline & Maximal increment $\$$ & 13.9 & 11.9 & 13.0 & 13.9 & 9.3 & 9.1 & 16.2 & 11.5 & & \\
\hline \multirow{2}{*}{$\begin{array}{l}\text { Plasma } \\
\text { growth } \\
\text { hormone }\end{array}$} & Maximum $\ddagger$ & 54.9 & 15.1 & 74.0 & 18.5 & 18.3 & 31.3 & 28.9 & 77.1 & 17.4 & 44.9 \\
\hline & Maximal increment $\S$ & 54.0 & 13.7 & 71.8 & 8.1 & 8.1 & 30.3 & 27.9 & 76.1 & 15.4 & 42.9 \\
\hline
\end{tabular}

* Minimal values 0 to 120 minutes after injection.

+ Sum of the values at 60,90 , and 120 minutes after injection as a percentage of the control value. ¥ Maximal values 0 to 120 minutes after injection.

\$ Maximal value 0 to 120 minutes after injection less value of control sample.

utes after insulin $(27.5 \pm 5.5 \mu \mathrm{g}$ per $100 \mathrm{ml})$ than did the males $(23.3 \pm 2.6 \mu \mathrm{g}$ per $100 \mathrm{ml})(\mathrm{p}<$ 0.05 ).

For the purpose of defining a normal range of response these minor differences were disregarded, and pooled results from the 28 subjects and patients are shown in Table III.

Reproducibility and time relationships of the resp.onses to insulin. Five of the control patients were retested with the same dose of insulin ( 0.15 $\mathrm{U}$ per $\mathrm{kg}$ ), and the results are summarized in $\mathrm{Ta}$ ble IV.

The plasma sugar, FFA, and cortisol responses were similar during the repeat tests, but maximal growth hormone levels and their maximal increment above the fasting value were grossly disparate, two- to fourfold differences being found.

In three control subjects blood samples were taken at 5 -minute intervals after the injection of insulin to determine the time relationships of the various responses. The increase in the circulating levels of FFA, cortisol, and growth hormone that occurred from 20 to 25 minutes after the injection of insulin preceded by 5 minutes the rise of the plasma sugar from its nadir.

\section{Discussion}

Of the various criteria that must be applied to any function test, such as specificity and reproducibility, that relating to safety is of paramount im- portance. Many clinicians have reservations concerning the use of a test based on the intravenous injection of insulin, especially in patients with hypothalamic or pituitary dysfunction (22). In our experience the diagnostic value of the responses to insulin outweighs the possible risk. No patient in the present studies experienced severe side effects, and the only complications encountered in an additional 300 tests have been coma (on two occasions) and angina (on two occasions), which responded promptly to the intravenous administration of glucose. Essential safeguards include the presence of a physician throughout the test, the avoidance of the test on patients with a history of epilepsy or of heart disease (because of the danger of precipitating angina or cardiac arrhythmias in the latter group) (23), the immediate availability of glucose for intravenous injection, and the use of an amount of insulin relating to the probable diagnosis. In this context we have not found it necessary to use less than $0.10 \mathrm{U}$ per $\mathrm{kg}$ even in patients with endocrine hypofunction. Finally, as Fraser (24) has emphasized, the patients should be given a meal at the end of their test and should eat regularly throughout the rest of the day to avoid the risk of hypoglycemia occurring after the completion of the test period. In our experience this risk is minimal if insulin is given intravenously (as opposed to subcutaneously or intramuscularly): 
It is important to standardize the preliminaries of the test in order to establish basal values. In particular the subjects must be fasted and must also be at rest, since there is a marked sex difference in the effect of exercise on plasma growth hormone levels. Thus Frantz and Rabkin (25) have shown that growth hormone values in women are increased even when exercise is limited to ambulation. It is a measure of effective standardization that we did not detect a significant sex difference. The tests were performed with an indwelling needle to avoid the stress of repeated venipunctures, since both emotional and physical stress has been shown previously to result in parallel rises in plasma cortisol and growth hormone (26). The use of an indwelling needle affords the additional advantage that glucose can be injected intravenously with minimal delay if severe side effects occur.

In three subjects plasma samples were obtained at 5-minute intervals after the injection of insulin in order to determine the time course of the plasma sugar, FFA, cortisol, and growth hormone responses. It was apparent from these studies that the determination of plasma sugar and FFA levels at 10-minute intervals for 1 hour and at 15minute intervals for a further hour allowed a reasonable approximation of their nadir and rate of recovery. It also appeared that the determination of plasma cortisol and growth hormone levels at 30-minute intervals was sufficient to determine their near maximal values. Five subjects were tested on two separate occasions. The plasma sugar, FFA, and cortisol responses were reproducible, but the plasma growth hormone responses were not. The response in the second test was not consistently lower or higher than that obtained in the first, and the reasons for the disparity in the growth hormone increments are not apparent. The reproducibility of the plasma cortisol rise mitigates against a variable element of stress as a reason for the variable growth hormone response. Sampling, however, was less than continuous, and the more rapid disappearance of growth hormone from plasma than cortisol may play some part in the variability of response.

The effects of injecting different amounts of insulin ( 0 to $0.15 \mathrm{U}$.per $\mathrm{kg}$ ) were studied in a group of control subjects. In the 2-hour period after an injection of saline, plasma sugar levels remained constant, FFA and growth hormone levels increased, and plasma cortisol levels fell. After the injection of insulin, plasma sugar and FFA levels fell to a nadir at 20 to 30 minutes and then returned to, or above, preinsulin values. The minimal levels found and the rate of recovery of the plasma sugar (but not of the plasma FFA) were related to insulin dosage. The injection of $0.05,0.10$, and $0.15 \mathrm{U}$ of insulin per $\mathrm{kg}$ resulted in a sustained plasma cortisol rise, detectable at $\mathbf{3 0}$ minutes and related to the amount of insulin administered. A significant elevation of growth hormone levels was observed in subjects given 0.025 , or more, $U$ per $\mathrm{kg}$. Growth hormone levels frequently showed marked fluctuations during the course of the test. An additional six patients were studied after the injection of $0.30 \mathrm{U}$ of insulin per $\mathrm{kg}$. The results in these patients were not included in the present paper, since they had peptic ulcers and since the tests were performed in conjunction with a Hollander insulin test (27), which involved the insertion of a stomach tube and continuous gastric aspiration. Their resting plasma cortisol and growth hormone levels were significantly raised, and calculation of the areas of their plasma sugar, FFA, cortisol, and growth hormone responses showed that they were less than expected from the relationships established over insulin doses from 0 to $0.15 \mathrm{U}$ per $\mathrm{kg}$. Stress may have played a significant but unknown part in the responses, or responses may be maximal at the $0.15 \mathrm{U}$ per $\mathrm{kg}$ dose level.

The responses to $0.15 \mathrm{U}$ of insulin per kg were studied in a group of 22 control patients. Their results did not differ significantly from those obtained in members of the medical staff, and the responses were not related to age or weight over the age and weight ranges studied. Significant sex differences were found in relation to the mean plasma sugar nadir and the mean plasma cortisol value at 90 minutes.

The main purpose of the present investigation was to determine the normal range of the plasma sugar, FFA, cortisol, and growth hormone responses to insulin for subsequent comparison with the responses found in patients with a variety of pathological conditions. The criteria of a normal test (see Table III) were kept relatively simple in order to have clinical practicability and took into account the great variability of the growth hor- 
mone response. The use of an over-all range for each index studied resulted in differences related to sex being operationally insignificant. The range of normal responses was found to encompass the results previously reported by other authors for plasma cortisol (5) and for growth hormone (6, $8,9,28,29$ ) when allowances were made for the different standards of human growth hormone used. We believe the criteria used will enable responses in subsequent tests to be graded as being "normal," "reduced," or "absent."

\section{Summary}

A rapid test of the hypothalamo-pituitary axis for the secretion of growth hormone and the hypothalamo-pituitary-adrenal axis for the secretion of cortisol is described.

Plasma sugar, free fatty acid, cortisol, and growth hormone were measured in 43 normal subjects before and at intervals for 2 hours after the intravenous injection of saline or various doses of insulin ( 0.025 to $0.15 \mathrm{U}$ per $\mathrm{kg}$ body weight). Estimates of the responses have been derived from the measurements and the changes intercorrelated and correlated with the dose of insulin. A normal range of responses has been defined and the time sequence of the changes studied. The reproducibility on repeat tests was found to be poor for the response in growth hormone. Sampling times in routine insulin tests are suggested and the safeguards and standardization of the test discussed.

\section{Acknowledgments}

We wish to thank Dr. G. F. Marrian, F.R.S., and Prof. A. Neuberger, F.R.S., for their interest and encouragement in this investigation, the physicians of St. Mary's Hospital and in particular Dr. V. Wynn for the opportunity to study their patients, and Dr. C. C. Spicer of the General Register Office for his advice on the statistical treatment of the results of dynamic tests. We gratefully acknowledge the technical assistance of Miss C. Harris and Mrs. J. Gray, and of the technicians in the Department of Chemical Pathology, St. Mary's Hospital, under the supervision of Dr. B. Houghton, and in the Steroid Laboratories under the supervision of Dr. V. H. T. James.

\section{References}

1. De Bodo, R. C., and N. Altszuler. Insulin hypersensitivity and physiological insulin antagonists. Physiol. Rev. 1958, 38, 389.
2. Williams, R. H. Textbook of Endocrinology. Philadelphia, London, W. B. Saunders, 1962, p. 715.

3. Fraser, R., G. F. Joplin, L. H. Opic, and D. Rabinowitz. The augmented insulin tolerance test for detecting insulin resistance. J. Endocr. 1962, 25, 299.

4. Amatruda, T. T., Jr., D. R. Hollingsworth, N. D. D'Esopa, V. Upton, and P. K. Bondy. A study of the mechanism of the steroid withdrawal syndrome. Evidence for integrity of the hypothalamic-pituitary-adrenal system. J. clin. Endocr. 1960, 20, 339.

5. Landon, J., V. Wynn, and V. H. T. James. The adrenocortical response to insulin-induced hypoglycaemia. J. Endocr. 1963, 27, 183.

6. Roth, J., S. M. Glick, R. S. Yalow, and S. A. Berson. Hypoglycemia: a potent stimulus to secretion of growth hormone. Science 1963, 140, 987.

7. Roth, J., S. M. Glick, R. S. Yalow, and S. A. Berson. Secretion of human growth hormone: physiologic and experimental modification. Metabolism 1963, $12,577$.

8. Hunter, W. M., and F. C. Greenwood. Studies on the secretion of human-pituitary-growth hormone. Brit. med. J. 1964, 1, 804.

9. Frantz, A. G., and M. T. Rabkin. Human growth hormone. Clinical measurement, response to hypoglycemia and suppression by corticosteroids. New Engl. J. Med. 1964, 271, 1375.

10. Abrams, R. L., M. Parker, S. Blanco, S. Reichlin, and W. H. Daughaday. Hypothalamic regulation of growth hormone secretion (abstract). J. clin. Invest. 1964, 43, 1242.

11. Landon, J., F. C. Greenwood, T. C. B. Stamp, and V. Wynn. The plasma sugar, free fatty acid, cortisol, and growth hormone response to insulin and the comparison of this procedure with other tests of pituitary and adrenal function. II. In patients with hypothalamic or pituitary dysfunction or anorexia nervosa. J. clin. Invest. 1966, 45, 437.

12. James, V. H. T., F. C. Greenwood, J. Landon, and V. Wynn. The plasma sugar, cortisol, and growth hormone response to insulin. III. In patients with elevated plasma levels of endogenous or exogenous steroids. In preparation.

13. Hoffman, W. S. A rapid photoelectric method for the determination of glucose in blood and urine. J. biol. Chem. 1937, 120, 51.

14. Marks, V., and K. Lloyd. The enzymatic measurement of glucose by autoanalysis. Proc. Ass. clin. Biochem. 1963, 2, 176.

15. Dole, V. P., and H. Meinertz. Microdetermination of long-chain fatty acids in plasma and tissues. J. biol. Chem. 1960, 235, 2595.

16. Mattingly, D. A simple fluorimetric method for the estimation of free 11-hydroxycorticoids in human plasma. J. clin. Path. 1962, 15, 374.

17. Kruger, F. A., R. G. Wieland, D. E. Maynard, S. H. Schachner, and G. J. Hamwi. Comparison of 
fluorimetric corticoids and Porter-Silber 17-hydroxycorticoids during fasting. Metabolism 1965, 14, 199.

18. Hunter, W. M., and F. C. Greenwood. A radio-immunoelectrophoretic assay for human growth hormone. Biochem. J. 1964, 91, 43.

19. Raben, M. S. Human growth hormone. Recent Progr. Hormone Res. 1959, 15, 71.

20. Brownlee, K. A. Industrial Experimentation, 4th ed. London, H.M.S.O., 1953.

21. Wilkins, G. A. Interpolation and Allied Tables. London, H. M. Nautical Almanac Office, H.M.S.O., 1961, p. 70.

22. Ross, E. J. The endocrinology of pituitary tumours. Proc. roy. Soc. Med. 1961, 54, 621.

23. Leak, D., and P. Starr. The mechanism of arrhythmias during insulin-induced hypoglycemia. Amer. Heart J. 1962, 63, 688.
24. Fraser, R. Endocrine disorders and insulin action. Brit. med. Bull. 1960, 16, 242.

25. Frantz, A. G., and M. T. Rabkin. Estrogen stimulation of growth hormone release (abstract). J. clin. Invest. $1965,44,1048$.

26. Greenwood, F. C., and J. Landon. Growth hormone secretion in response to stress in man. Submitted for publication.

27. Weinstein, V. A., R. Colp, F. Hollander, and E. E. Jemerin. Vagotomy in the therapy of peptic ulcer. Surg. Gynec. Obstet. 1944, 79, 297.

28. Beck, P., J. H. T. Koumans, C. A. Winterling, M. F. Stein, W. H. Daughaday, and D. M. Kipnis. Studies of insulin and growth hormone secretion in human obesity. J. Lab. clin. Med. 1964, 64, 654.

29. Hartog, M., M. A. Gaafar, and R. Fraser. Effect of corticosteroids on serum growth hormone. Lancet $1964,2,376$.

\section{SPECIAL NOTICE TO SUBSCRIBERS}

Post Offices will no longer forward the Journal when you move.

Please notify The Journal of Clinical Investigation, Business Office, 10 Stoughton Street, Boston, Mass. 02118, at once when you have a change of address, and do not omit the Zip Code number. 